\title{
DECLINING TO LEARN FROM THE EAST? THE WORLD BANK ON 'GOVERNANCE AND DEVELOPMENT'1
}

Mick Moore

\section{INTRODUCTION}

The World Bank's recent policy statement on 'good government' - Governance and Development (1992), (henceforth termed 'Governance') - may, like many of the Bank's major policy statements, be interpreted in two different ways. One may take it at face value, as a statement of: what the Bank thinks are the important governance issues with which it is able to deal given the limitation imposed by its 'non-political' mandate; what the Bank has been doing in the governance field; and what it proposes to do in future. Alternatively, one may read 'Governance' as a set of signals intended to influence the thinking of the rest of the world, notably the governments of the Bank's client countries, about what constitutes good government, and therefore what they should themselves be doing independently of the Bank. 'Governance' appears to have been written with this latter role in mind. While it contains a great deal of explicit and implicit qualification about the difficulties of making useful generalizations about such a vast, often-nebulous and generally contested subject, the document is organized around the proposition that there is a small and memorable number (four) of key dimensions of governance: (i) public sector management; (ii) accountability; (iii) the legal framework for development; and (iv) information and transparency. The outside world may forget, or never read, what 'Governance' has to say in detail about, for example, 'accountability', but, because accountability is one of the major themes, the idea will now receive more attention. ${ }^{2}$

In this article I am concerned with 'Governance's signalling role: with the question of whether it constitutes a good guide to 'good government' generally. This is an important question, because 'Governance' will be taken seriously. The excellence of the World's Bank's organization and the sophistication of its dissemination and outreach activities mean that its views are generally widely propagated and respected. 'Governance', however, has a special claim to attention in the context of the 'good government' debate. For the policy statements now emanating from other aid donors, especially governments of major bilateral donors, tend to be relatively militant and

\footnotetext{
II am grateful to Anne-Marie Goetz, John Healey, Jim Manor and John Toye for very helpful responses to an earlier draft of this article.

2 I have, for example, noticed, in a couple of Anglophone developing countries, that the term 'transparency' has very recently begun to appear rather frequently in public debate.
}

provocative in asserting that (multi-party) democracy and civil liberties are essential components of 'good government', and conditions for aid. By contrast, 'Governance' is both relatively modest and measured in tone and, what is more important, avoids these formof-government dimensions of the 'good government' agenda that are most likely to kindle dispute and resentment.

The concept of 'governance' is defined rather loosely 'as the manner in which power is exercised in the management of a country's economic and social resources for development' (p.1). 'Governance' makes a useful distinction between three different aspects of the concept of governance and essentially confines itself to the 'procedural' dimensions:

(i) the form of political regime (parliamentary/presidential, military/civilian, authoritarian/democratic); (ii) the processes by which authority is exercised in the management of a country's economic and social resources; and (iii) the capacity of governments to design, formulate, and implement policies, and, in general, to discharge government functions. The first aspect clearly falls outside the Bank's mandate (p.58).

Further, and consistent with its primary banking role, the Bank sees its governance mandate to lie essentially in areas that impinge directly on economic policy and management. It avoids the more contentious aspects of the 'good government' agenda and establishes a plausible claim to be dealing with the more practical aspects of greatest long run significance. Given also that 'Governance' is the product of a task force of 22 Bank staff, was something like two years in gestation, and has been accompanied by a serious research effort, ${ }^{3}$ it can claim considerable weight in comparison with the sparse but assertive statements on governance emanating from other aid donors. It is the most thoughtful extant official contribution to the 'good government' debate.

It is not of immediate concern here whether the World Bank will be successful in persuading its critics and clients that 'Governance' and the active promotion of

\footnotetext{
${ }^{3}$ The amount of political science research work done by World Bank staff has increased considerably since 'governance' became an issue. Some of the written output is more sophisticated and open-minded than 'Governance' itself. See for example Paul (1991 and 1992); and Brautigam (1991).
} 
'good governance' do not trespass on 'political' issues that are outside the Bank's mandate. Evidently the line the Bank tries to draw between what is and is not 'political' is fragile and perhaps ephemeral. ${ }^{4} \mathrm{It}$ is a line that the Bank is obliged to draw because its own constitution prohibits engagement in 'politics'. I refer at the end of the article to some of the consequences of this 'non-political' approach to political issues.

\section{AGENDA}

The issues covered in 'Governance' are vast - much of the combined subject matter of political science, government and political philosophy. It would be easy, at least for the erudite, to amass illustrations of how the authors - who anyway had only 60 pages at their disposal - simplified complex issues, ignored important topics, and generally made the world appear more clear-cut than it is in reality. That is not my intention here, because that is not centrally relevant to my purpose of assessing whether 'Governance' is indeed a good guide to 'good government' from the perspective of those who are not prepared to wait for the political theorists to come up with definitive answers, but want to do something about governance now. As other articles in this Bulletin indicate, we do not have very clear or settled ideas about what 'good government' might mean. From the perspective of this action-oriented clientele, the main question to ask about 'Governance' is: Is it helpful? To answer that, we may focus on three subsidiary questions: (i) Are the major particular arguments broadly correct? (ii) Does it draw attention to the most important governance issues? (iii) Does it provide an appropriate sense of the existence (or not) of choices and alternatives?

There is a great deal in 'Governance' that is valuable. This article focuses on its limitations, for it is often not very helpful, failing to focus on the kinds of issues that need attention. It is, however, difficult to make a summary evaluation of 'Governance' because it is not entirely clear where it is targeted. The document itself suggests that it may be targeted on three different but overlapping categories of countries. ${ }^{5}$ Judgements about its usefulness are not necessarily the same for each category.

1 Insofar as 'Governance' is primarily directed at the countries of sub-Saharan Africa - but couched in universalistic terms for diplomatic reasons - then its central messages are relatively appropriate and useful. In this environment, where many political systems are very fragile, where personalistic and arbitrary rule through direct force is relatively common, and where ideas of toleration of opposition and of critique of governments are weakly institutionalized, it is appropriate to stress the benefits of the rule of law, of accountability of public figures for the use of public resources, and of the provision of information on the actions and processes of government agencies. Conversely, in such situations, where polities are both fragile and predatory, it may be idle or even harmful to encourage a more positive vision of the role of the state. The correct emphases may be on (a) getting the state undertake very basic functions effectively and (b) minimizing the potential for state agencies to do damage. ${ }^{6}$

2 Insofar as 'Governance' is directed at those countries in 'Eastern Europe, Latin America and parts of Asia and Africa' which have undergone 'rapid political changes' (implicitly, the end of socialist rule, democratization or the adoption of 'market socialism') (p.5), then an overall judgment is difficult to reach. Some points are useful, notably the emphasis on law. But it is not clear how helpful it is to countries in the midst of major politico-economic transitions and crises to receive guidance about good government that is couched at a high level of generality and does not address issues of priorities and phasing during crisis and transition.

3 If one interprets the paper as an attempt to draw general lessons about governance for the full range of (developing) countries, it is open to serious question. The re are a number of relatively specific shortcomings, dealt with in Sections 3 to 7 below, notably the opaqueness of the idea of accountability and a very unsatisfactory discussion of law. These shortcomings however reflect a cluster of related ideological and procedural biases: invalid generalization from particular (especially Anglo-American) historical experiences; a general prejudice against most types of public action (except law making), and consequent disregard of the mechanisms and resources needed to make some types of effective public action possible; and blindness to the difficult problems faced and the political strategies required to overcome political disorder and establish any viable state system. In sum, and in ways that will be

\footnotetext{
${ }^{4}$ The Bank does not appear obsessed with staying on the 'safe' side of that line. There is in 'Governance' itself some open criticisms of the relatively sensitive topic of military expediture (p.46).

"See in particular the discussion on pp.4-5 of the stimulus behind 'Governance'. One might also note that the document addresses a further constituency in a semi-explicit fashion: the World Bank's own staff. It appears to reassure them about the (restricted) scope of the Bank's role in this potentially dangerous area and provides some guidance about how they should handle governance issues.
} 
explained in more detail below, 'Governance' is very much an ideological product, and one that reflects currently dominant Anglo-American/liberal/pluralist socio-political doctrine.

I attempt in succeeding sections to examine in detail some aspects of this ideological bias. A discussion of the procedure used by the 'Governance' task force to reach their conclusions however provides an essential general context to the more specific issues.

The history of thought around governance issues is deep and rich. And many of the important issues are what political theorists would term 'essentially contested': attitudes and perceptions reflect such widely diverging beliefs about society that no agreement can reasonably be expected.? When the World Bank is producing a document on governance that is intended to be authoritative, one would expect some statement about the organization of the processes of research, thought and discussion. How were the conclusions reached? Why are the four chosen issues believed to be so important? What alternatives were considered and rejected? There is no such statement in 'Governance'. We are asked to take on trust the conclusions of 22 Bank staff.

This demand for transparency within the covers of the 'Governance' document itself may be brushed aside; it is after all much what one would expect from an academic! The more important point is that there is an obvious procedure that the 'Governance' task force could and should have used which they did not follow. Recall that the declared focus is on those aspects of governance that impinge most directly on economic performance through the quality of policymaking and implementation. Given this focus, it would have been appropriate for the task force to adopt the following procedure:

1 Classify (developing) countries in terms of their relative economic performance (however defined) over some appropriate recent period.

2 Examine actual governance patterns in (a sample of) countries exhibiting different rates of economic performance.

3 Determine the extent to which variations in economic performance could reasonably be attributed to differences in governance.
4 Identify the key features of these more successful systems of economic governance and then appraise them for more general applicability.

However operationalized, such a procedure would lead to a substantial focus on East Asia: on Japan if more industrialised countries were to be included; certainly on South Korea and Taiwan; and perhaps on the city states of Hong Kong and Singapore. ${ }^{8}$ This would not have been especially problematic in an intellectual sense because of the relative abundance and excellence of recent research on the causes of good economic performance in East Asia, and the openness of the region to further research. In fact, the East Asian experience appears to have been largely ignored. ${ }^{9}$ One does not have to be a fanatical believer in the 'transferability' of East Asian experiences to other environments to see the value of empirical examination of the bases of success and failure. Without this empirical basis, the 'Governance' task force appears to have relied heavily on what they would presumably wish to characterize as 'wisdom', 'experience', or 'common sense', but what is undoubtedly doctrine the doctrine that currently dominates the World Bank, to the increasing irritation of the increasingly influential Japanese government: ${ }^{10}$ 'Anglo-American liberalism'.

\section{WHAT IS MISSING?}

In Sections 4 to 7, I examine separately what 'Governance' has to say about each of its 'four key dimensions of governance.' Before doing that, it is worth drawing attention to two potential candidates not included in that list.

Firstly, it is nowhere said that the reconstruction (or first-time construction in some cases) of a 'proper' senior civil service - with professional training and socialization, high status (and rewards), and a degree of neutrality and insulation from partisan politics would be an important contribution to improving governance. This is surprising given the high degree of support which this idea has among professional experts (see, for example, Leonard in this Bulletin), and the fact that the World Bank does indeed fund such activities in sub-Saharan Africa. Silence on this issue may partly reflect continuing sensitivities about being labelled 'élitist'. It is however congruent with the

\footnotetext{
${ }^{7}$ Take the very term 'government'. To many people this has a positive connotation: it is a 'good'. Yet to many other people, including those from anarchist-cum-communitarian intellectual traditions and contemporary neo-liberals, as well as people who have experienced 'government' mainly as armed oppression, the very term has negative connotations. The list of 'essentially contested' political terms is long. For a general discussion, see Connolly (1983).

${ }^{8}$ At least by virtue of recent rates of economic growth, China might also be considered for inclusion.
}

\footnotetext{
${ }^{9}$ It is striking that there appears to have been little accumulated experience of East Asia among the 22 members of the 'Governance' task force, and that only one of the $m$ has a name that indicates East Asian origins. This is surprisingly low even considering the overall predominance of European names: of the small number of nonEuropean names, five are clearly South Asian (World Bank 1991:57).

${ }^{10}$ See for example reports of critical Japanese responses to World Bank policy prescriptions in the Far Eastern Economic Review of March 12 and June 181992.
} 
general neo-liberal distrust of public bureaucracies, which emerges again in the way in which 'Governance' deals with the issue of accountability (see Section 5).

Secondly, despite the fact that the World Bank's concern with good government is rooted in the implications for economic performance, it makes no mention of a concept describing a dimension of good economic governance rapidly gaining currency among economists: 'government credibility'." The essence of this concern is simple: that a major determinant of the effectiveness of a government's economic policies is the extent to which, on the basis of past performance and other considerations, other market actors (including other governments) believe that government to be honest in its intentions and statements and to have a realistic understanding of its own capacities. While this concept derives mainly from the realm of macroeconomic management in industrial countries, it has very evident application, for example, to the management of the transition from statist to market economic regimes. Its omission may reflect the political science and public administration biases of 'Governance'.

\section{PUBLIC SECTOR MANAGEMENT}

'Public sector management' is not discussed at great length in 'Governance', because it is the subject of a separate paper, already in print (World Bank 1991). The focus is on the effective management of the main resources which governments control - money and personnel - and the main target is practices that permit inefficient deployment of these resources, including weak budgeting and accounting, excessive public sector employment, and loose controls over the parastatal sector. These are relatively concrete problems over which there is a substantial consensus; structural adjustment programmes already underway tend to target these kinds of issues. Their inclusion in 'Governance' as the first in the list of significant governance issues seems sensible and reasonable.

\section{ACCOUNTABILITY}

'Accountability' is potentially the most potent of the Bank's four key dimensions of good government. It is a single, familiar word that has unambiguously positive connotations. We know what the Bank is saying; we understand that they are saying that it is a good thing, and thus the more of it the better. The message seems very clear.

'Accountability, at its simplest, means holding public officials responsible for their actions' ('Governance', p.13). It does seem to be an excellent thing when presented in these terms. And so it is. If the alternative to 'accountability' is 'no accountability', then it would be difficult to imagine circumstances in which one would not be unambiguously in favour of it. Public servants who are given positions and public resources without any kind of oversight into the uses made of them will rarely deploy them honestly, energetically or efficiently. Thus far we can agree with 'Governance'. This is also the point to say that, independently of the more critical note of succeeding paragraphs, if one believes that accountability in general is a rare commodity in some countries (in sub-Saharan Africa or elsewhere), then it seems appropriate for 'Governance' to emphasize the idea in the reasonable hope that more attention will be paid to it.

The problem is that, once 'accountability' has done this rather limited job, it is not clear that 'Governance' has very much more that is helpful to say on the issue. For 'accountability' is a highly abstract concept, sometimes interpreted in formalistic and legalistic terms, and sometimes used in a more concrete way to refer to the social, economic, political, etc. mechanisms through which some agents become responsive to other agents. Its real world manifestations are diverse, differentiated and, in some cases, partially in contradiction with one another. One cannot usefully discuss particular instances without tackling at least three questions: Accountability to whom? Through what mechanisms? And to what degree? 'Governance' does not provide much guidance about how to 'unpackage' the general concept so that one can begin to see how different mechanisms, variants and degrees of it may be useful in different circumstances. And 'Governance' tends to devalue certain standard accountability mechanisms internal to public bureaucracies in favour of (useful and important but nevertheless) limited ideas about accountability to 'the people'.

There is a large literature on the concept of accountability. Most of it is less helpful than it could be because of failure to make explicit that any effective process of accountability actually comprises two relatively distinct but serially-related sub-processes, which may be undertaken by different agents and through different mechanisms:

1 An appraisal process, through which the performance (effectiveness, efficiency, honesty, energy, etc.) of any public agent/agency is investigated or monitored and judgements are made.

2 A sanctioning process, through which authoritative action is taken to reward (and thus encourage) good performance and penalize (and thus discourage) bad performance.

"I am grateful to Jean-Philippe Platteau for pointing this out. 
Effective accountability mechanisms must find ways of addressing both these processes. Many so-called 'accountability mechanisms' do not. For example, the great weakness of democratic accountability is that, while voters have considerable sanctioning power through their capacity to replace governments, they typically lack appraisal power: they do not have the information and expertise to make good judgements about the very complex issues with which governments routinely deal. Conversely, and more concretely, the financial accountability of Sri Lankan government institutions to Parliament through the AuditorGeneral works well at the appraisal stage - the Auditor-General publishes regular, honest and hardhitting reports - but largely fails at the sanctioning stage because successive governments have mainly chosen to ignore these reports.

This appraisal-sanctioning distinction helps reveal the limitations of the conceptual work on types of accountability mechanisms which underpins 'Governance'. The notion that there are three main mechanisms - 'democratic', 'professional' and 'legal' accountability ${ }^{12}$ - does not seem to take us very far. In practice, more than one may have to be combined for accountability to be effective. 'Professional' mechanisms may lead a public servant to publicize the fact that his Minister is misusing public money, but, if sanctioning is to take place, then some mechanism falling under the 'democratic' or 'legal' labels has to be brought into play. We can in fact get more purchase on the issues by being more empirical, listing the main channels through which holders of any kind of public office may in practice be responsive to other parties:

a Public servants may be accountable to their bureaucratic superiors for work performance and for adherence to correct procedure.

b Through independent scrutiny mechanisms internal to the public service, such as Auditor-Generals and Ombudsmen, public servants may be accountable to an external political authority - to Parliament in the 'Westminster' tradition.

c Public servants belonging to professional groups formal or informal - may be responsive to - or formally accountable to, in some cases - their professional peers for their ethics and performance (see Leonard in this Bulletin).

d Public servants may have to answer before committees of the legislature for their practices and performance.

e Public servants may be responsive to politicians, both to their formal political masters (Ministers) and to other politicians who have influence over their appointment, salary, promotion, transfer, reputation, etc.

12 These are the three main mechanisms identified in a relatively sophisticated discussion of the concept of accountability in a related f The 'executive' as a whole - Ministers and the public bureaucracy - may be accountable to the legislature, especially for funds.

g Public servants and politicians may be responsive to 'clients' among the public, whether, for example, poor villagers who manage to get publicity for the fact that their famine rations have not been delivered, or groups of powerful business executives who will make a fuss if the Ministry decides to cease bending an ambiguous rule in their favour in the determination of the value of import duty rebates.

h Public servants and politicians may be responsive to anyone able to take them to law for illegal conduct.

i Politicians may be responsive to voters.

This list may appear elementary and formal, but it does serve to illustrate a number of points about accountability that are ignored in 'Governance':

1 Different types of accountability may contradict one another. For example, being more responsive to 'clients' might involve short cuts through departmental procedures, and thus less accountability to bureaucratic superiors.

2 Some types of accountability may not be good, including for example the accountability of public agencies to powerful and self-interested pressure groups.

3 More accountability is not unambiguously a good thing. The advocates of totally open and transparent government have always been with us. Realists cannot afford to back them all the way. Total accountability would disable governments in many respects. For example, senior public servants must be free to give some types of advice on sensitive issues without their involvement becoming generally known. If they feared exposure to hostile politicians, pressure groups or public, they might refuse to give frank advice at all.

It is not my intention here simply to point out the complexities of the world; they are always with us. One purpose is to point out that 'Governance' gives little guidance about dealing with them. Once one moves away from a base line situation in which there is little accountability of any kind, the simple insistence on the concept is not very helpful. It does not help one to decide how to make the choices and compromises that need to be made between competing ends and alternative means to those ends. 'Governance' discusses four main issues under the label 'accountability' accounting/auditing, decentralization, 'micro-level accountability' of public agencies to the direct consumers of locally provided services, and government

World Bank document produced by one of the main contributors to the discussion of accountability in 'Governance' (Paul 1991). 
and NGOs (non-governmental organizations) ${ }^{13}$ without any statement of priority. It is not even the case that these areas are being implicitly identified as the sites for positive action to enhance accountability: much of the discussion of decentralization focuses on the dangers of the process from the perspective of budgetary control (pp.21-22).

My second purpose is here to point out that 'Governance' does bear a message about the importance of different types of accountability with broad implications that are not made very explicit. There is a clear emphasis on the 'micro-level accountability of public agencies to the direct consumers of locally provided services' mentioned above. This is generally positive. As 'Governance' usefully explains, micro-level accountability 'has become more important as the role of the state has expanded and made it impossible to apply broad political accountability to all the myriad actions of modern government' (p.14). 'Governance' is in fact backed up by a considerable amount of sophisticated research and conceptual debate on microlevel accountability, building largely on the concepts of 'exit', 'voice' and 'access' initially popularized by A. O. Hirschman (Paul 1991, 1992). One can reasonably anticipate that some useful practical results will emerge. But, at the same time, it seems that some of the more conventional accountability mechanisms many of them in great disarray in many developing countries and elsewhere - have been rather ignored. Indeed, the intra-bureaucracy mechanisms, such as $\mathbf{a}$ to $\mathbf{d}$ in the list above, are explicity identified as untrustworthy:

... except for legal accountability for government action in some countries, accountability has mostly been by internal administrative controls by political leaders, government agencies and bureaucrats acting as proxies for the public. But hierarchical control is often ineffective, especially when collusion between supervisory and subordinate personnel is likely (p.14).

While I both agree with that statement and am very keen on finding new mechanisms to control public bureaucracies externally, especially mechanisms of competition (Moore 1992), I would not write-off internal (or 'hierarchical') controls so easily. No potentially useful tool should be laid aside. Is there some causal connection between (a) the Bank's apparent willingness to lay these aside and (b) continuing pressures to be seen to be responding to neo-liberal doctrine, which has little faith in the capacity of the public service to regulate itself?

13 There is clearly an element of fashionability here; it is not clear that there is any particular connection between NGOs and accountability.

14 I use the term 'Western constitutional principles' deliberately. For 'Governance' assumes the traditional Western distinction between legislative, executive and judicial powers and agencies. There are functioning alternatives that merit some claim to consideration,
Finally, what else might the authors of 'Governance' have done to make their discussion of accountability more useful? In the first place, they might have tried to build-in some kind of protection against their own 'buzz words' being used for undesirable purposes. For example, there is nothing to stop a President who is in the process of replacing his professional civil servants by new cadres nominated by 'the masses' (i.e. the ruling political party) not only from claiming, as some have done in the past, that this is a way of making the public service 'more accountable to the masses', but also in claiming that this is fully in accord with the emphasis that the World Bank places on accountability. The term excludes less than it should if it is to be very serviceable.

In the second place, the authors of 'Governance' might have supplemented their standard 'constitutional' approach to the issue of accountability with some indication that there exist effective accountability mechanisms, appropriate to particular circumstances, which do not correspond to formal or constitutional mechanisms, but represent the fruit of local learning and ingenuity. Taiwan provides such an example in relation to irrigation management. Contrary to received impressions, there is little direct connection between the acknowledged efficiency of Irrigation Associations and the facts that they are formally controlled by elected farmers' representatives and depend for (some of) their finance on irrigation fees paid by farmers. However, the monitoring by central government agencies of the speed with which farmers pay their irrigation fees after the due date constitutes a means through which farmer dissatisfaction is signalled. It is a heterodox but effective mechanism for keeping the Associations responsive ('accountable') to the farmers they are supposed to serve (Moore 1989). The World Bank can probably contribute much more to the goal of improved accountability by seeking out and publicizing such cases than by re-hashing standard, 'Western' constitutional principles. ${ }^{14}$

\section{THE LEGAL FRAMEWORK OF DEVELOPMENT}

The most powerful single point that 'Governance' has to make under this heading is summarized in the sentence: 'In Eastern Europe, the lack of a legal system conducive to private sector development is a severe impediment to privatization and new investment' (p.4). That is a proposition with which one can wholeheartedly agree. To put the issue in rather more general terms, one can see the need to give priority to the introduction

notably the traditional Chinese distinction among three types of government institution: those with the power of decision, the power of execution and the power of supervision (Vandermeersch 1985). One might also note that, in the companion review of 'Governance and Economy', the only historical experience considered in any detail is that of Western Europe (Brautigam 1991: 6-9). 
of an effective system of commercial law in circumstances where (a) because of a recent radical change of politico-economic regime, no such legal system exists; and (b) the new economic policy involves rapid integration into the global economy and, thus, a high volume of new economic transactions with foreign economic agents concerned about the security of their assets. That situation currently characterizes a significant fraction of the countries of the world, and it is only appropriate that they should be reminded of the need to do something about commercial law.

However, and somewhat analogous to the argument above about accountability, I believe that, once these relatively extreme cases have been dealt with - and I include here as 'extreme' those situations only referred to very allusively in 'Governance' in which legality is in general ignored by those who have state power - the discussion of law is not of much practical help. In this case however I would go a little further, and suggest that, in relation to law, 'Governance' (a) could be positively misleading in some respects; and (3) clearly reveals the cultural and ideological biases at work in the World Bank. More precisely, 'Governance' exhibits a faith in the power of the legal process and an implicit belief that 'the more law, the better' which is not even 'Western' or 'Anglo-American', but peculiarly American - and at odds with a great deal of evidence from many parts of the world.

Most of what 'Governance' has to say about the legal framework for development appears at first sight sensible and unexceptionable. It talks not of the more abstract or ideological issues implicit in such notions as 'fairness' and 'liberty', but focuses 'on a more basic level: the processes of formulating and applying rules' (p.30). The type of issues considered are summarized thus:

Five critical elements are considered: (a) there is a set of rules known in advance, (b) the rules are actually in force, (c) there are mechanisms ensuring application of the rules, (d) conflicts are resolved through binding decisions of an independent judicial body, and (e) there are procedures for amending the rules when they no longer serve their purpose (p.5).

My concerns about the discussion of law generally arise not from what is said in 'Governance', but from what is left unsaid, and thus about the overall message conveyed. There is no suggestion or hint that changes in the law, including the extension of the law into new areas, can actually cause problems and perhaps generate more costs than benefits. There is no indication that different legal systems perform very differently, and that there are real choices available. The implicit message is that law is a good thing, the more the better, and that there is little difference between different legal systems - the key categorical distinction appears to be between 'law' and 'no law'.

The nearest that 'Governance' comes to a positively misleading statement about law is the following: '. . . only (emphasis added) governments can provide two sorts of public goods: rules to make markets work efficiently and ...'(p.6). This is as good a point as any from which to start a critique.

As mentioned above, there are circumstances, such as those of contemporary Eastern Europe, where governments need to play a central role in providing a legal framework to guide market transactions. It is however contrary to a great deal of evidence to infer from this that reliable, predictable and orderly market transactions await the provision of such a legal framework. Had this been the case, most of the world's population would probably have starved to death by now. Markets are to a very high degree self-regulating. Relations of trust are built up between business people in the course of doing business. It is fear of losing a particular business link and, more importantly, of losing a reputation for trustworthiness - and thus losing business - in information-rich social-cumbusiness circles that constitute the dominant contraints on cheating. Formal legal institutions play a minor role in comparison with social institutions in making the market economy possible.

Evidence on this point is available from a variety of sources. A well-known paper by Granovetter (Granovetter 1985) summarizes it from a sociological perspective. Historians have investigated how the institutional and sociological sources of business trust change when business conditions alter (Zucker 1986). Recent research by the World Bank's own staff on 'The legal and regulatory environment for business transactions in Brazil and Chile' leads to the conclusion that law is relatively insignificant. Informal mechanisms may often be superior for dealing with such matters as credit referencing and debt collection. The authors conclude that 'the findings warn against a preoccupation with formal legal and regulatory reform as an immediate means to promote economic development; in the eyes of Brazilian entrepreneurs, problems relating to legal and regulatory institutions take a distinct backseat to macroeconomic and political instability' (Stone et al. 1992: 1). The same kind of conclusion can be derived more impressionistically, but on a far more significant scale, from the impressive performance of the East Asian economies over recent decades. A recurring theme in commentaries on the region is the insignificance of law in regulating business transactions. ${ }^{15}$ This constitutes as near a refutation as one can imagine of the implicit proposition in

\footnotetext{
${ }^{15}$ For some evidence on Taiwan, see Wade (1990: 269-70).
} 
'Governance' that effective commercial law is essential to (fast) economic growth.

Were the issue simply that law is often redundant, then efforts put into improving the legal system would be less beneficial than expected, but no harm would result. The emphasis placed on law in 'Governance' is however open to question on the grounds that the potential costs of law and legal process are underplayed. 'Governance' deals with two kinds of costs: (a) the costs of having no formal law - which I have suggested may be lower than they appear in relation to commercial transactions; and (b) the costs (monetary, time, delay, uncertainty) arising from inadequate legal process and institutions - retrospective legislation, lack of information on what the law actually is, lengthy legal process, etc. The comments made on the latter type of costs generally appear valid and plausible. 'Governance' is however silent on the costs which may be imposed on society by what might appear, in its terms, to constitute good law (and legal process).

The extension of ('good') law can itself be counterproductive. A classic example relates to the introduction of 'modern' individual ownership rights to land hitherto held under some kind of informal or 'customary' tenure. The arguments for individualization at first sight appear persuasive. This will end the uncertainty associated with customary tenure, and, by giving the individual clear ownership of land improvements (planting long term tree crops, soil conservation measures, etc.), encourage investment. And clear title will provide the collateral needed to obtain the credit to finance investment. The reality can be very different. The process of formalizing rights may create conflicts, incentives to divert energies into contests over legal title, opportunities for the aggressive and well connected to benefit themselves at the expense of others, and long-standing uncertainty over rights (Attwood 1990; Platteau 1992). There can be a major difference between (a) the image of a legally-regulated society and (b) the reality of what happens when formal law is introduced.

The more general question is whether the (American) model implicit in 'Governance' - of an active and 'user friendly' adversarial legal system widely resorted to in cases of dispute - is actually a good thing (for anyone except lawyers). The perspective represented by 'Governance' tends to underplay the costs involved. These fall into three categories:

1 The direct resource costs of (frequent, long) litigation to the parties directly involved.
2 The social and economic costs of the long term rupturing of social relationships between the parties that is almost inherent in the adversarial procedure. Two companies which have taken their disagreements to court are unlikely to do business together again.

3 Most importantly, the indirect social costs incurred when other people 'insure' themselves against the relatively high probability of being taken to court. Various types of 'insurance behaviour', all of them consumers of scarce resources, may result. One is 'insurance' in the financial sense: e.g. stereotypically, the enormous medical practice insurance premiums paid by American doctors. The enormously long and complex contracts that American companies tend to insist on having signed before they will do business represent another type of insurance and cost. Another type of insurance behaviour, impossible to measure, is abstinence from potential transactions for fear of liability to legal action if things go wrong. How much urgent but risky medical attention is not provided in America for fear that the doctor may become vulnerable to legal action? How much business is not done because a satisfactory contract cannot be drawn up or because litigation is feared when one party takes a risk?

We do not know the answer to these particular questions, or to all the others that arise when socioeconomic relations become deeply embedded in an active, adversarial legal system. But we do know that there is an alternative model of legalism that has been associated with a very low incidence of resort to courts or other formal judgement, very low crime rates, a thriving private sector economy, and a general reputation for social and civic responsibility - Japan..$^{16}$ Further, we know that, regardless of whether or not this pattern of behaviour can be said to have a 'cultural' origin, it clearly stems in part - as changes over time reveal - from specific institutional arrangements that could relatively easily be introduced elsewhere. Japanese citizens behave quite 'rationally' (defined narrowly here as 'pursuing individual material interests') when they resort to the courts far less frequently than many other nations. Japanese court procedures are lengthy and expensive. But there are strong incentives to settle (civil) issues out of court. For court judgements are relatively predictable, ${ }^{17}$ and so parties in dispute, knowing what the likely outcome of a court settlement would be, can negotiate an agreement among themselves without incurring court costs (Haley 1978; Ramseyer 1988).

In the Japanese system, legal judgements are made in such a way that they constitute guidelines for the

\footnotetext{
${ }^{16}$ And, one should add, relatively few and relatively lowlyremunerated lawyers. I am indebted to Ron Dore for references on this topic.
} 
peaceful resolution of analogous disputes outside the court process - a clear contrast to the high degree of unpredictability and 'pro-court bias' of the AngloAmerican adversarial system. One would not have wanted 'Governance' simply to recommend the general adoption of these Japanese principles. One could have reasonably expected an acknowledgement that there are widely differing legal systems, and that, instead of only struggling to make existing (generally Westerninspired) legal systems operate as they were intended, poor countries might well look at alternative systems -from countries which have been more successful economically than 'the West' in recent decades - to see whether or not they have something to offer.

\section{INFORMATION AND TRANSPARENCY}

Having accepted that there are special cases where it is not in the interests of states to make information widely available, 'Governance' argues that 'there are three areas in which improved information and greater transparency are beneficial: economic efficiency (information to enable markets to function more efficiently - MM); transparency as a means of preventing corruption; and the importance of information in the analysis, articulation and acceptance of policy choices' (p.39). There is scope here for considerable debate about the extent of the 'special exceptions'. 'Governance' cites security issues and planned changes in exchange rates as possible exceptions, and implies that there should be few others. By contrast, it could be argued that economic competition between modern states is in some respects analogous to warfare, and that there is in fact a wide category of economic information that may sometimes best be treated as if it were 'strategic' in the military sense. For example, Taiwan's relatively generous access to Western markets for its exports over a long period of time was obtained in part by an extremely non-transparent system of import licensing that both disguised the true extent of restrictions and provided incentives and mechanisms for would-be importers to identify local potential suppliers (Wade 1990: 121-6 and 130-3). Knowledge of the truth would have led to retaliation in Western markets.

Attitudes to this general issue will closely reflect positions in the debate about desirable types and degrees of economic interventionism by states. 'Governance' mirrors the standard, relatively minimalist position of the World Bank. Subject to reservations on this particular issue, what it has to say on the subject of information and transparency in government appears broadly useful and correct.

\section{CONCLUDING COMMENTS}

For many centuries, two contrasting views of the nature of politics and the role of government competed in Western Europe. In Continental Europe

the prime fact of political experience is (i.e. 'was' MPM) the continuous threat, potential or actual, that each country poses to its neighbour's boundaries and the ensuing continuous struggle for an equilibrium acceptable to all countries involved. Under these conditions, political praxis and thought necessarily turn outward, according the highest priority to diplomacy and war.

By contrast, in England, the

country protected by the sea from the direct and continuous threat of aggressive neighbours, political thought and praxis naturally turn inward, adopting as their standard the well-being of the commonwealth . . Here, public controversy, the safeguarding of rights, and the framing and enforcing of laws appear as the very essence of political business (Poggi 1978: 10).

(Historians, please accept this purposeful simplification).

The continental tradition was essentially statist: effective government was essential for security, and a high degree of trust was necessarily reposed in government. There was nothing intrinsically suspect about the idea that the state would sometimes play a leading role in promoting new technologies or new forms of economic organization. By contrast, the English tradition, transferred in a relatively extreme form to fertile soil of pioneer America in the 17th century, starts from an essential distrust of government and belief that society - whether in the shape of landlords, merchants, markets or 'common' law (i.e. law embodied in practice, tradition and previous judgements rather than in formal legal codes drawn up by state agencies) - can best be left to sort out its own problems. Law, constitutionality and electoral representation were valued above all as means of checking the potential power of the state and preserving the dominance of society over it. ${ }^{18}$ Since the end of World War Two, the liberal and pluralist Anglo-American doctrine has been in the ascendant throughout Western Europe. The recent ideological and political collapse of state socialism has been seen by some observers as an unquestioned victory for this economic and political liberalism and the prelude to its global dominance (Fukuyama 1992). ${ }^{19}$

\footnotetext{
${ }^{18}$ This contrast is explored at length in Dyson (1980) and Poggi (1978).

${ }^{19}$ Despite its overt abstinence from strident doctrinal assertion,
}

'Governance' is a product and an expression, albeit dilute, of the contemporary triumphalism of liberal ideology. 
The shifting fortunes of doctrines are one thing. The realities of political power are quite another. The contemporary states of Western Europe and North America are not the frail and delicate creatures of liberal and pluralist imagery, mere instruments of the contending groups and interests which bargain with one another in the electoral arena. They are powerful machines, endowed with large and reliable financial resources, considerable organizational power, privileged access to vast amounts of information, a significant capacity to take the lead in representing what they define to be the interests of their citizens in international fora, and, in most cases, a high capacity to shape 'social interests' through corporatist arrangements for the representation of these interests in policymaking fora (Cawson 1986). All states are based on some combination of force and consent. The contemporary states of Western Europe and North America enjoy both considerable capacities to exercise 'force' over society and high levels of 'social consent'.

Much of the rest of the world is not like this. 'Lack of political order' - the simple inability of governments to govern - has never been so evident as at present. The list above of governmental 'goods' is often reversed. It is not simply that large numbers of citizens reject 'their' government. In addition, governments have acute financial problems, lack organizational and administrative capacity, have little reliable information, and are very vulnerable to pressures from powerful organized interests, local and foreign.

The authors of 'Governance' might broadly agree with this description of the governance problem. However, their prescriptions may not be simply inadequate, but useless or worse, at least if taken in isolation. For 'Governance' provides a remedy for basic problems of political disorder only to the extent that there is validity in the liberal-pluralist assumption that citizens will behave better in relation to the state to the extent that the state ceases to exploit and tyrannize them, and generally treats them in a 'constitutional' fashion. There is considerable truth there, but not enough. For political order does not easily or generally follow on the demise of state tyranny. It is not an outgrowth of nature, but a product manufactured by politicians and state makers. And the production processes are rarely sweet smelling or harmonious, but noisy, nasty and, often, cruel. The liberal-pluralist paradigm provides little guidance about how to construct and maintain political order. Neither is there any guidebook to which we can refer. ${ }^{20}$
If there were such a guidebook, it might deal with the following kinds of issues:

1 The need for governments to perform symbolic and moral roles - to give their citizens a sense of purpose, and a reason, normally couched in terms of participation in some historic enterprise (Anderson 1983: Ch 2), why they should behave decently toward one another. In the contemporary world, most political leaders are faced with a choice between two kinds of historic enterprise: one is the welfare of a particular ethnic group (or coalition of such groups), and the other is the 'development' of the nation state. There are relatively few cases where boundaries of ethnic group and nation can be made to coincide without pain, such that no choice need be made. In most cases a choice is needed, and the likelihood that the world will become a more decent place for many people depends in part on the proportion of cases in which the 'developmental' rather than the ethnic definition of historical enterprise is successfully implanted. For the latter leads very directly to open conflict. The capacities of rigorously and consciously liberal governments to implant and nourish developmentalism are relatively limited: if 'development' is an historic mission, and a government is to obtain legitimacy through promoting 'development', then the liberal doctrine that the government that is least active is ultimately the most effective becomes singularly useless from the political perspective. Governments need to be seen to be actively involved; the 'hands-off' state has few claims to political legitimacy.

2 Permitting social interests - occupational, ethnic, regional or whatever - unrestrained liberty and space to organize as they will to represent themselves in policymaking in most circumstances a recipe for chaos. Small but powerful interests might be enabled to dominate part of the state apparatus, to the general social detriment. A great deal of unproductive squabbiing might ensue between competing representatives of the same or similar interests. ${ }^{21}$ And a government interested in co-operating with social interests in formulating and implementing policy might find stable, reliable and authoritative representation difficult to come by. All governments worthy of the title engage to some degree in 'co-optive' or 'corporatist' practices to shape the way in which societal interests are represented. There is considerable debate about whether, given a plurality of objectives and a prejudice in favour of freedom, such corporatism is best restricted to the 'societal corporatism' which dominates the advanced industrial countries, or whether, given the exigencies of underdevelopment, there is a case for the more authoritarian 'state corporatism' of the type that has been practised, to some degree, in East Asia (Wade 1990: 372-7), and has,

21 For a discussion of this in relation to the representation of business interests, see Moore and Hamalai (1993).
${ }^{20}$ Machiavelli's lead in this matter is something to which later writers on politics have rarely felt willing or able to emulate. 
for example, enabled the Mexican government to persuade trades unions to suppress wage demands in recent years and contribute to a rapid economic recovery. ${ }^{22}$ Whatever the answer to that question, good governments need to act in relation to interest groups. ${ }^{23}$

3 The use of public resources - jobs, subsidies, grants, and projects - for purposes of political patronage represent, from the economist's perspective, waste and corruption. From the perspective of the politician and the political scientist, some patronage is essential in every polity, and quite a large amount may be needed in polities which are otherwise so frail that they threaten to fall apart. Governments need to 'buy' support, and cannot rely on the hope of long run economic grow th to keep conspirators from the door. If they do not 'buy' a reasonable core of support at strategic points in the polity, they will not last. There is little point in re-hashing this debate from extreme positions of general principle. Can one instead identify or design patronage systems that are politically effective but impose relatively low economic costs on society? 'One way to raise political returns while lowering economic costs is for benefits to be provided in such a way that they can be given again, rather than constituting a permanent drain on the resources of the state' (Leonard 1987: 901). Do not give graduate veterinarians and paramedics a job in the public service, but a subsidy to permit them to establish themselves as independent practitioners (especially in needy areas). Do not build expensive feeder roads, but pay the material cost of their periodic rehabilitation if the people served are prepared to contribute their labour (Leonard 1987: 902). Learn from the Harambee (self-help) system as established in Kenya under President Kenyatta: making public support for local schools, health clinics, feeder roads, cattle dips, etc. conditional on substantial initial local contributions (a) helps limit demands on public funds; (b) creates a genuine interdependence between local politicians and their constituents which both keeps local politicians responsive to local needs and diverts them from attempting to serve these needs through influencing major policy decisions at the political centre (Barkan 1992: 175-8).

The general point is that 'political management' may not be a recognized discipline, but is a valuable art and one in which the world has many accomplished practitioners. It is possible to learn from example and the interpretation of others' experiences how polities may be nurtured and maintained without bankrupting and destroying economies. The World Bank is willing to help empower society in developing countries to keep a close eye on the state and make sure that it does not become too powerful. But it is unwilling and unable to look after the other side: to take state-building seriously and to provide equivalent resources to support political learning. In this sense the notion that 'Governance' avoids politics is unquestionably false. The paradox is that serious attention to improving these explicitly political dimensions of governance may be an urgent practical need.

inimical to good economic management, and would have to be controlled by 'firm' government if policies of structural adjustment and economic liberalization were to be successfully implemented (Toye 1992). Now, in response to the peaceful popular 'uprisings' in Eastern Europe of 1989-91, and the hegemony of liberal-pluralist Ideology, active and powerful interest groups, re-labelled as 'civil society', are seen as a central to good social order.

\section{REFERENCES}

Anderson, B., 1983, Imagined Communities. Reflections on the Origin and Spread of Nationalism, Verso, London

Attwood, D. A., 1990, 'Land registration in Africa: the impact on agricultural production', World Development, Vol 18 No 5: $659-672$

Barkan, J., 1992, 'The rise and fall of a governance realm in Kenya', in G. Hyden and M. Bratton (eds), Governance and Politics in Africa, Lynne Rienner, Boulder, Colorado and London

Brautigam, D., 1991, 'Governance and economy: a review', Policy Research Working Papers, WPS 815, The World Bank, Washington DC
Cawson, A., 1986, Corporatism in Political Theory, Basil Blackwell, Oxford

Connolly, W. E., 1983, The Terms of Political Discourse, 2nd ed, Martin Robertson, Oxford

Dyson, K., 1980, The State Tradition in Western Europe, Martin Robertson, Oxford

Fukuyama, F, 1992, The End of History and the Last Man, Hamish Hamilton, London

Granovetter, M., 1985, 'Economic action and social structure: the problem of embeddedness', American fournal of Sociology, Vol 91 No 3: 481-510 
Haley, J. O., 1978, 'The Myth of the Reluctant Litigant', The Fournal of Fapanese Studies, Vol 4 No 2: 359-390

Leonard, D. K., 1987, 'The realities of African management', World Development, Vol 15 No 7: 899-910

Moore, M., 1989, 'The fruits and fallacies of neo-liberalism: the case of irrigation policy', World Development, Vol 17 No 11: 1733-1750

-1992, 'Competition and Innovation in Development Administration', IDS Bulletin, Vol 23 No 4

Moore, M. and L. Hamalai, 1993, 'Economic liberalization, political pluralism and business associations in developing countries', IDS Discussion Paper No 318

Stone, A., Levy, B. and Paredes, R., 1992, 'Public institutions and private transactions: the legal and regulatory environment for business transactions in Brazil and Chile', Policy Research Working Papers, WPS 891, The World Bank, Washington DC

Paul, S., 1991, 'Strengthening public service accountability. A conceptual framework', World Bank Discussion Papers, 136, The World Bank, Washington DC

-1992, 'Accountability in public services: exit, voice and control', World Development, Vol 20 No 7: 1047-1061

Platteau, J-P., 1992, 'Formalization and privatization of land rights in sub-Saharan Africa: a critique of current orthodoxies and structural adjustment programmes', DEP 34, London School of Economics, Development Economics Research Programme
Poggi, G., 1978, The Development of the Modern State: A Sociological Introduction, Hutchinson, London

Ramseyer, J. M., 1988, 'Reluctant litigant revisited', The fournal of Japanese Studies, Vol 14 No 1: 111-124

Toye, J., 1992, 'Interest group politics and the implementation of adjustment policies in sub-Saharan Africa', fournal of International Development, Vol 4 No 2: 183-197

Vandermeersch, L., 1985, 'An enquiry into the Chinese conception of law', in S. R. Schram (ed.), The Scope of State Power in China, School of Oriental and African Studies, London

Wade, R., 1990, Governing the Market; Economic Theory and the Role of Government in East Asian Industrialization, Princeton University Press, Princeton, NJ

World Bank, 1991, 'Managing development: the governance dimension. A discussion paper', Discussion Paper, The World Bank, Washington DC

-1991, 'The reform of public sector management: lessons of experience', Policy Research Series, 18, The World Bank, Washington DC

Zucker, L., 1986, 'Production of trust: institutional sources of economic structure, 1840-1920', Research in Organizational Behaviour, Vol No 8: 53-111 